\title{
The Effect of Isolated Obestatin Hormone from Plasma on some Biochemical Parameters in Normal and Diabetic Rats
}

\author{
Thikra A. Allwsh \\ Department of Chemistry \\ College of Science \\ University of Mosul
}

\author{
Jehan A. Mohammad \\ Department of Clinical Laboratory Science \\ College of Pharmacy \\ University of Mosul
}

(Received 2/4/2013 ; Accepted 10/6/2013)

\begin{abstract}
The study included an attempt to isolate and purify obestatin from healthy human plasma using different biochemical techniques. Two proteinous peaks had been isolated by gel filtration chromatography (Sephadex G-50) from the precipitate produced by precipitation using cold acetone. It was found that the second peak (peak B) only had an obestatin. Two proteinous components had also been isolated by the same technique using Sephadex G-25 from the peak B. It was found that the second peak (peak D) had a high concentration of obestatin .

Furthermore, the purity of the isolated obestatin (peak D) had been identified by the reversed phase high performance liquid chromatography and by SDS-polyacrylamide gel electrophoresis technique. The results obtained from the RP-HPLC showed that there was a good identity in retention time between the standard and the isolated obestatin (peak D).

The approximate molecular weight of partially purified obestatin was $(2573 \pm 100 \mathrm{Da})$ and (2660 Da) using gel filtration chromatography by Sephadex G-25 and ( SDS-PAGE) technique respectively.

The effect of the isolated obestatin (peak D) on some biochemical parameters in normal and alloxan induced diabetic male rats had been studied. After one week of treatment, the results showed that the obestatin at the dose $(1 \mu \mathrm{mol} / \mathrm{kg}$ of body weight / d $)$ caused a significant decrease in the levels of glucose, total lipids, total cholesterol, triglycerides, LDL-C, VLDL-C and MDA, in a addition to a significant increase in the levels of HDL-C in normal and alloxan induced diabetic rats and GSH in alloxan induced diabetic rats.

It was concluded that the isolated obestatin from plasma had a an important role in metabolism of glucose and lipid profile in normal and alloxan induced diabetic rats.
\end{abstract}

Keywords: Obestatin hormone, biochemical parameters, diabetes. 


\section{تأثثير هرهن الأوستالتين المعزط من بلازما العم عل بهض المتغيرات الكيموحيوبة النكور الجرذلن اللسليمة والمصلبة بداء السكر}

\section{الملغص}

تضمن البهث عزل وتقية هرمون الأوبستانين من بلازما شخص سليم بلستخده القنيلت الحياتية

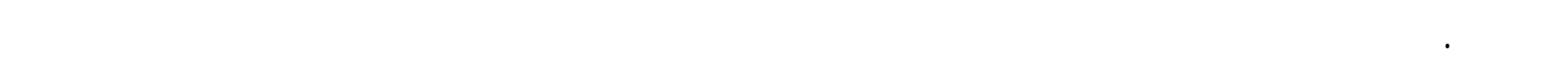

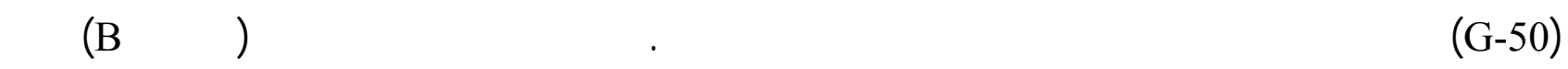

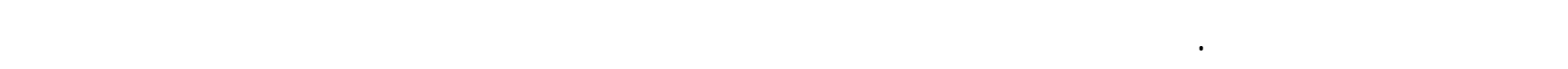
اللسيفكس (G-25) للحزمة البروتينية (الحزمة B) الناتجة من فقنية الترشبح الهلامي (Sephadex G-50)

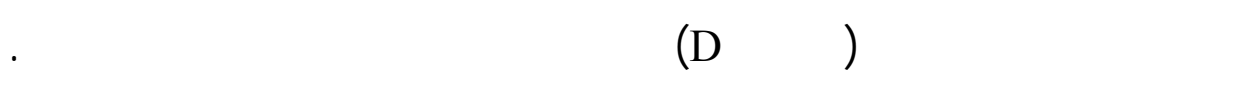

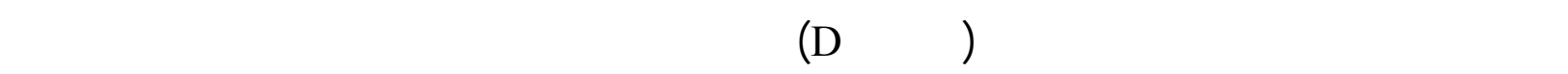
اللسايل عالي الأداء. ولوظظ وجود ظابق في وقت الاحتبلس لهرموني الأوبستاتين القيلسي والمعزول

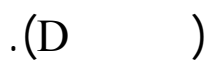

كما حدد الوزن الجزيئي القريبي لهرمون الأوبستاتين بلستخدلم الترشبح الهلامي بهلام للسفكس والهجرة الكهربائية بلستخدلم SDS وكلن Da Da 100 ـ 2573) و( 2660) على التوالي.

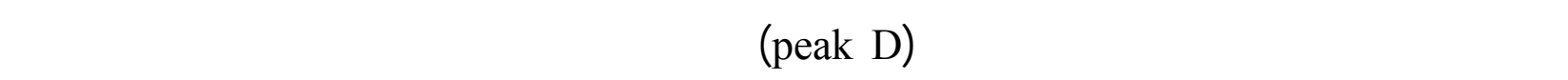

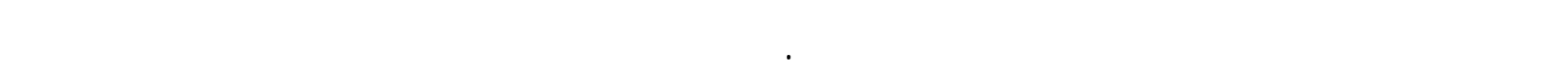

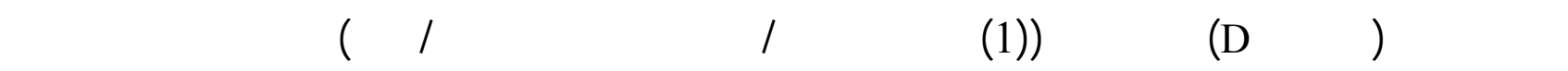

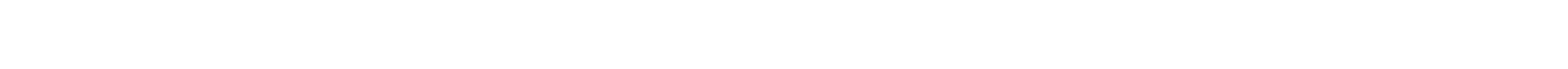

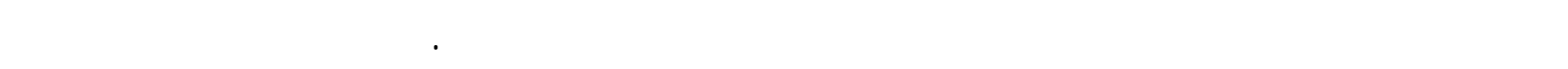
في مستوى كولسترول البروتين الدهني عالي الكثافة في الجرذان للسليمة والمصابة بداء للسكر المستحدث بالالوكسان، وكذك مستوى الكلوتاثايون في الجرذان المصابة بداء للسكر المستحدث بالالالوكسان.

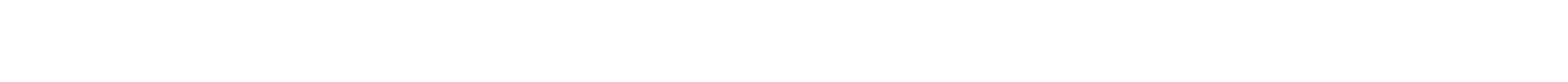
والدهون في الجرذان اللسليمة والمصابة بداء اللسكر المستحدث بالالوكسان.

الكاملت الدالة: هرمون الأوبستاتنن، متغيرات كيموحيوية، داء للسكر. 


\section{INTRODUCTION}

In 2005, it was discovered that 23 amino acids amidated peptide was called obestatin hormone. It was firstly isolated and purified from the rat stomach using high-performance liquid chromatography (HPLC) of Sep-Pak C18 and fractionated using a sephadex G50 gel filtration column (Zhang et al., 2005). The most obestatin producing cells in the stomach were distributed in the basal part of the oxyntic mucosa (Jahan et al., 2011). As well as, it is present in plasma (Mondal et al., 2008), adipose tissue (Granata et al., 2012) and different peripheral tissues (Ren et al., 2009).

Obestatin is a peptide hormone that is derived from the C-terminal part of the mammalian preproghrelin gene that also encodes ghrelin. It was found to interact with the orphan receptor G-protein coupled receptor 39 (GPR 39) (Zhang et al., 2005; 2008; Dong et al., 2009) and to oppose the stimulatory effect of ghrelin on food intake and gastrointestinal motility (Zhang et al., 2005; Ishitobi et al., 2012). It was also circulated in blood as an endocrine hormone (Semi et al., 2011)

Many studies showed that obestatin promoted the survival of $\beta$-cells and regulated the endocrine pancreatic function (Volante et al., 2009; Granata et al., 2010), insulin biosynthesis, and antiapoptic actions in pancreatic $\beta$-cells (Granata et al., 2008). It was also inhibited glucose induced insulin secretion, prevented lipolysis (Ren et al., 2008; Granata et al., 2012) and regulated energy balance (Zhang et al., 2005).

The aim of this research is to isolate and purify obestatin from human plasma, and study its effect on diabetes induced in the experimental animals.

\section{Isolation and purification of obestatin from plasma \\ MATERIALS AND METHODS \\ - Sample:}

A human fresh plasma $(50 \mathrm{ml})$ was obtained from only one healthy male person, his age (30 years), weigh $(70 \mathrm{~kg}$ ) with the assistance of blood bank in Mosul city.

Obestatin hormone was purified from plasma as following:

\section{I- Organic solvent precipitation:}

Proteinous materials were precipitated by using acetone (Zhang et al., 2005). Gradual addition of cold acetone $(60: 40 \mathrm{v} / \mathrm{v})$ to plasma with slowly stirring at $4{ }^{\circ} \mathrm{C}$ for $60 \mathrm{~min}$. The mixture was left in the refrigerator for $24 \mathrm{~h}$ and the precipitated protein was isolated by centrifugation for 30 minutes $(10000 \times \mathrm{g})$ in a cooling centrifuge. Protein concentration was estimated after dissolving the precipitate in a lowest volume of distilled water. The solution of proteinous precipitate was kept in a tight sample tube for next step.

\section{II- Gel filtration chromatography:}

Two columns were used in this research

A- The first: It has a dimension of $(2 \times 100 \mathrm{~cm})$ which filled by a sephadex G-50 gel. The proteinous precipitate solution prepared in section (I) was added to this column and eluted with distilled water. The fractions was collected at flow rate $(88 \mathrm{ml} / \mathrm{h})$.

B- The second: It has a dimension of $(1.21 \times 110 \mathrm{~cm})$, was filled by sephadex G-25 gel. The proteinous material which was obtained from the first column (peak B which contains obestatin hormone) was added to this column and eluted with distilled water. The fractions were collected at $68 \mathrm{ml} /$ hour. Protein and obestatin concentrations were estimated at each step of isolation. 
The comparative molecular weight of proteinous peaks (B and D) which contains obestatin hormone was obtained from its elution volume under the same conditions of known molecular weight in both columns. Peak B (from the first column) and peak D (from the second column) were dried by freeze dryer technique.

\section{III- Electrophoresis}

A sample from (peak D) which contains a high obestatin concentration was applied on SDS-PAGE (Laemmli, 1970) using slab electro apparatus (Mediphor Heidelberg Dosage, Germany). This analysis was performed in the Department of Chemistry / College of Science.

\section{IV- High performance liquid chromatography (HPLC)}

A sample from (peak D) and standard obestatin (CUSBIO, China) were applied on C18 RP-HPLC (Agilent 1200 series, USA). This analysis was performed in the state Company for Drug Industries and Medical Appliances in Nineveh.

\section{Obestatin assay}

Obestatin concentration was determined by enzyme linked immunosorbent assay (ELISA) technique (Cuping and Dongmei, 2009) using CUSBIO kit (China). This analysis was performed in the immunity laboratory in Al-Salam Hospital in Mosul City, BIO-TEK INSTRUMENTS, USA.

\section{Determination of protein concentration}

The concentration of protein was determined by the modified of lowery (Schacterle and Pollack, 1973), and using bovine serum albumin as a standard (its extinction coefficient equal to 0.67 ).

The second part of experimental part focused on studding the effect of obestatin (which was isolated and purified from human plasma by different techniques) on the diabetic rats.

Effect of isolated obestatin hormone (peak D) in normal and alloxan-induced diabetic rats

Animals used

Male albino rats (24) weighing ( $300 \pm 35 \mathrm{~g})$, obtained from animal house, College of Veterinary Medicine, University of Mosul were used in the experiments. They were housed under standard environmental conditions, are the pelleted food and water were available ad Libitum.

\section{Induction of diabetes}

The animals were fasted for $(24 \mathrm{~h})$ and the diabetic was induced by injecting them with alloxan tetrahydrate $(180 \mathrm{mg} / \mathrm{kg}$, i.p) dissolved in sterile normal saline (Miura et al., 1995). The diabetic state was monitored by hyperglycemia (Colorimetric assay kit, BIOLABO, France) along the next ten days. Rats with blood glucose level more than $(250 \mathrm{mg} / \mathrm{dl})$ were considered diabetic and used for study.

\section{Experimental design}

The dose of the isolated obestatin hormone was $(1 \mu \mathrm{mol})$. The dose used for intraperitoneal injection was selected on the basis that was the same as used in several previous in vivo studies (Zhang et al., 2005; Green et al., 2007; Subasinghage et al., 2010; Granata et al., 2012). The rats were divided randomly into four groups, each contained six rats: 
1. The first group was normal rats injected intraperitoneally with physiological saline solution and served as a control group.

2. The second group was alloxan -induced diabetic rats and considered to be a control diabetic group.

3. The third group was injected intraperitoneally with $(1 \mu \mathrm{mol} / \mathrm{kg}$ of body weight/d $)$ of isolated obestatin (peak D).

4. The fourth group (alloxan induced diabetic rats) was injected intraperitoneally with ( $1 \mu \mathrm{mol} / \mathrm{kg}$ of body weight/d) isolated obestatin (peak D). All the groups were injected for one week.

\section{Collection of blood}

Fasting blood samples (16 h) were collected from four groups by orbital sinus puncture technique, using capillary tube without anticoagulant (Tomoda et al., 1990). Serum was separated and used to estimate the following biochemical parameters:

Blood glucose was determined immediately by the enzymatic colorimetric method (Trinder, 1969). Total lipids was determined by colorimetric method manually (Chabrol and Chardonnet, 1937). Total cholesterol was determined by enzymatic colorimetric method (Allian et al., 1974). Triglycerides was determined by enzymatic colorimetric method (Fossati and Prencipe, 1982). High density lipoprotein-cholesterol (HDL-C) was determined by precipitation method (Lopez-Virella et al., 1977), using BIOLABO kit (France), but the low density lipoprotein - cholesterol (LDL-C) was calculated using the following equation. LDL-C $(\mathrm{mmol} / \mathrm{L})=$ Total cholesterol - HDL-C-T.G conc. $(\mathrm{mmol} / \mathrm{L}) / 2.2$ (Burtis and Ashwood, 1982).

Very low density lipoprotein - cholesterol (VLDL-C) was calculated using the following equation:

VLDL-C conc. (mmol/L): T.G conc. (mmol/L)/2.2 (Fischbach, 2000). Glutathione was determined manually according to the modified method of (Sedlak and Lindsay, 1968), malondialdehyde was determined manually by the modiefied method of (Guidet and Shah, 1989). Alkalin phosphatase and acid phosphatase activity were determined manually according to the (kind and King, 1954) method. Glutamate and pyruvate transaminase and the glutamate oxaloacetate transaminase activity were determined by a colorimetric method manually (Reitman and Frankel, 1957).

\section{Statistical analysis}

The data obtained in the current study was analyzed using statistical package for social science (SPSS).

1. Standard statistical method was used to determine the mean and standard error.

2. Independ - sample T-test is used to compare between two parameters.

3. One way anova (Duncan-test) is used to compare between more than two parameters.

4. P-value $\leq 0.05$ was considered to be statistically significant (Kirkwood, 1988).

\section{Isolation and purification of obestatin}

\section{RESULTS AND DISCUSSION}

The precipitate obtained from plasma by cold acetone precipitation high concentration of obestatin $(332.34 \mathrm{pg} / \mathrm{ml})$ compared with plasma $(301.44 \mathrm{pg} / \mathrm{ml})$ while the filtrate has not any obestatin hormone. So, the filtrate was neglected.

Gel filtration chromatography was applied to separate the protein as a source of obestatin hormone by using two columns as following: 
First column: This technique was applied to separate the proteinous materials, which were obtained by acetone precipitation method from human plasma. The results of elution is shown in (Fig. 1) which indicated that there were two main peaks (A and B). The elution volume of peak A and B were $(86.3 \mathrm{ml}),(255.9 \mathrm{ml})$ respectively. Only the peak (B) was obtained has a high concentration of obestatin hormone. The peak (B) was broad and represented by two interfered peaks. So, gel filtration (sephadex G-25) was used to purify this peak.

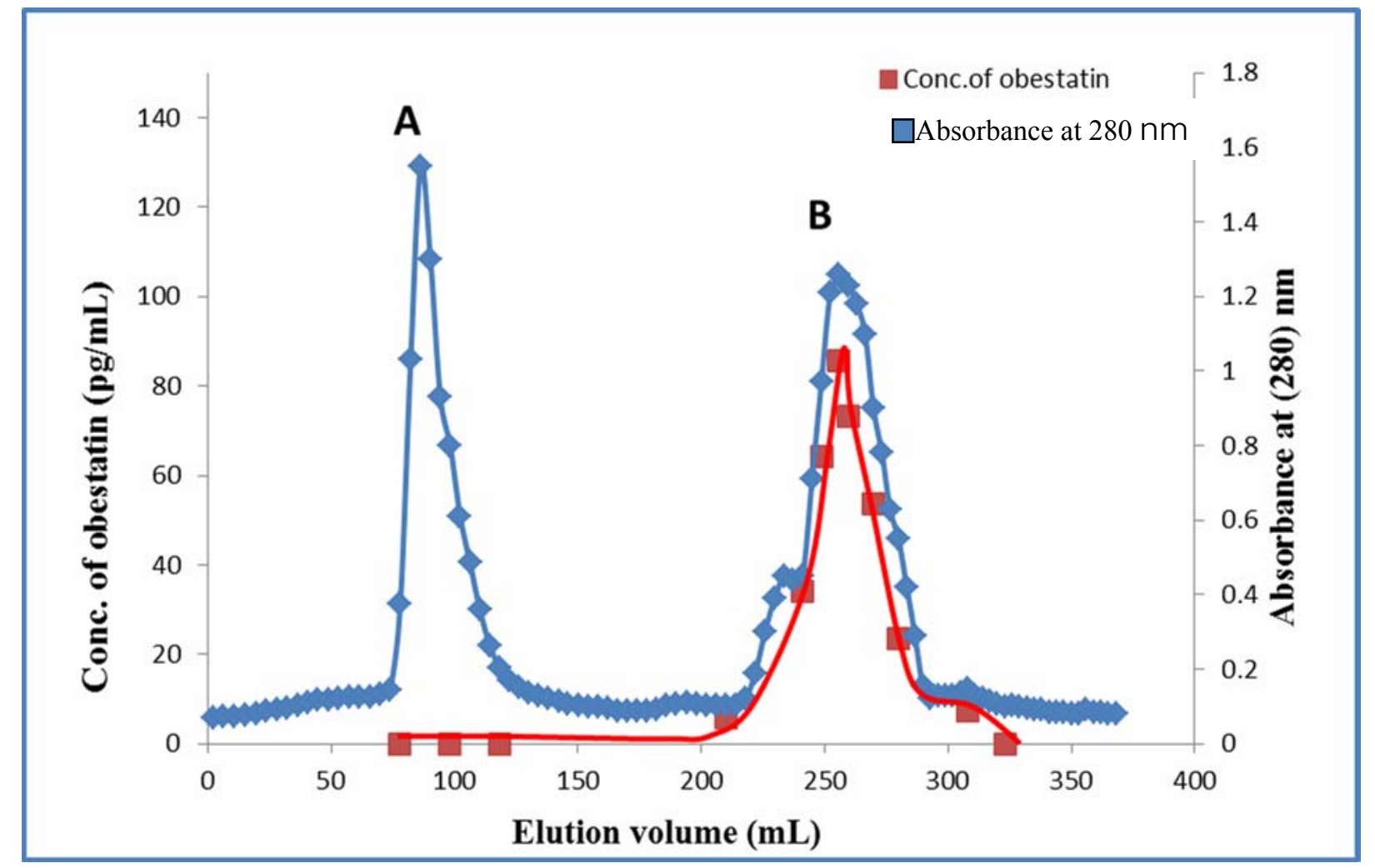

Fig. 1: Elution profile of prteinous precipitate solution obtained from acetone precipitation on Sephadex G-50. The dimension of the column is $(2 \times 100 \mathrm{~cm})$ at the flow rate is $(88 \mathrm{ml} / \mathrm{h})$

Second column: This technique was applied to separate the proteinous materials, obtained from the first column gel filtration (peak B). The results of elution as shown in (Fig. 2), indicated that there were two peaks $(\mathrm{C}$ and $\mathrm{D})$. The elution volume of peak $(\mathrm{C}$ and $\mathrm{D})$ were $(39.8 \mathrm{ml}),(112.5 \mathrm{ml})$ respectively. The peak $\mathrm{D}$ has obtained with high concentration of obestatin hormone. So, the peak (C) was neglected.

The results of all purification steps for obestatin hormone were listed in Table (1). 


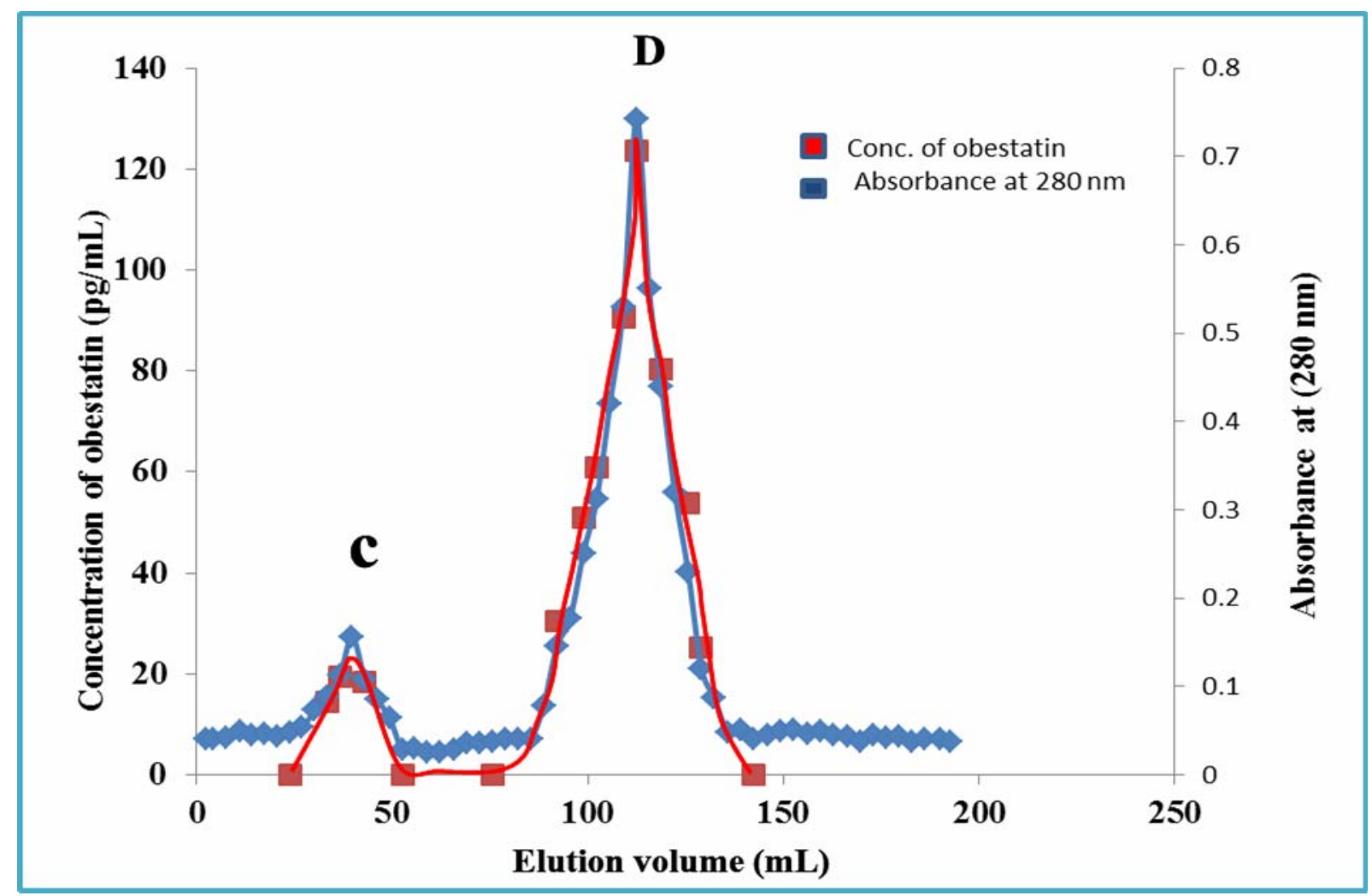

Fig. 2: Elution profile of peak (B), using Sephadex G-50 on Sephadex G-25. The dimension of the column is $(1.21 \times 110 \mathrm{~cm})$ at a flow rate of $(68 \mathrm{ml} / \mathrm{h})$

Table 1: Partial purification of obestatin hormone from human plasma

\begin{tabular}{|c|c|c|c|c|c|c|}
\hline Purification steps & $\begin{array}{c}\text { Total } \\
\text { volume }\end{array}$ & $\begin{array}{c}\text { Total } \\
\text { protein } \\
\text { (mg/mL) }\end{array}$ & $\begin{array}{c}\text { Total conc. } \\
\text { of } \\
\text { obestatin } \\
\text { (pg/mL) }\end{array}$ & $\begin{array}{c}\text { Total } \\
\text { specific } \\
\text { conc. of } \\
\text { obestatin } \\
\text { (pg/ mg) }\end{array}$ & $\begin{array}{c}\text { Fold of } \\
\text { purification }\end{array}$ & $\begin{array}{c}\text { Recovery } \\
\text { \% }\end{array}$ \\
\hline Plasma & 50 & 398.00 & 15072.00 & 37.86 & 1 & 100 \\
\hline $\begin{array}{c}\text { Porteinous } \\
\text { precipitate solution }\end{array}$ & 38 & 236.74 & 14148.92 & 59.76 & 1.57 & 93.87 \\
\hline $\begin{array}{c}\text { Gel filtration } \\
\text { /Sephadex G-50 } \\
\text { (peak B) after } \\
\text { lyophilizer }\end{array}$ & 26 & 41.93 & 12503.66 & 298.14 & 7.87 & 82.95 \\
\hline $\begin{array}{c}\text { Gel filtration } \\
\text { /Sephadex G-25 } \\
\text { (peak D) after } \\
\text { lyophilizer }\end{array}$ & 25 & 7.25 & 11262.25 & 1553.41 & 41.02 & 74.72 \\
\hline
\end{tabular}

To check the purity of isolated obestatin hormone (peak D)from plasma, SDS-PAGE and RP-HPLC were used as shown below: 


\section{1- SDS-poly acrylamide gel electrophoresis}

Obestatin hormone (peak D isolated using sephadex G-25) exhibited only one single bond, using SDS-electrophoresis as shown in (Fig. 3). This result was in a highly agreement with previous results published by other investigators (Subasinghage et al., 2010; Alen et al., 2012; Raucci et al., 2013). Who found that obestatin hormone was a single peptide consist of (23 amino acids).

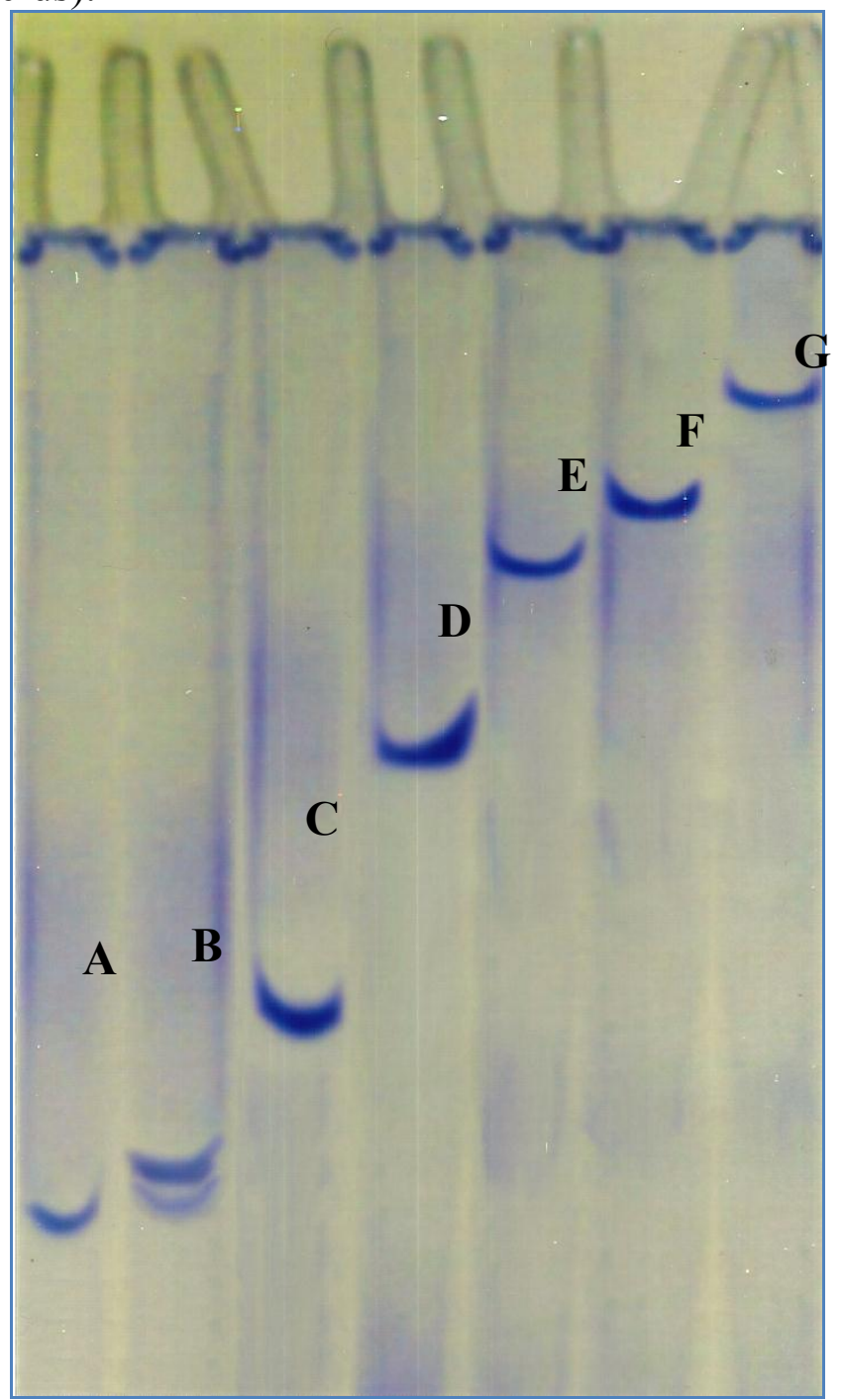

Fig. 3: SDS -polyacrylamide gel electrophoresis of partially purified obestatin hormone from plasma and known molecular weight proteins.

Band (A) represents (obestatin hormone) peak $D$ from gel filtration (sephadex G-25), band (B) insulin + $\beta$-ME, band (C) insulin without $\beta$-ME, band (D) for papein, band (E) for pepsin, band (F) for egg albumin, band (G) for $\alpha$-amylase. ( $\beta$-ME; is $\beta$-mercapto ethanol).

\section{2- RP-HPLC}

To determine the purity of obestatin hormone (peak D) the standard solution of obestatin was introduced into the RP-HPLC system to know it's retention time under the following conditions:

Flow rate: $0.5 \mathrm{ml} / \mathrm{min}$, Temp. Ambient, Wave length: 205.4, Pressure: $12 \mathrm{Mpa}$ 
Mobile phase: $(60: 40 \mathrm{v} / \mathrm{v})$ acetonitrile in $0.1 \%$ triflouroacetic acid.

The results in (Fig. 4) and Table (2) indicated that there were two peaks, the first and the second (main) peaks were appeared at (6.277) min., (6.713) min respectively.

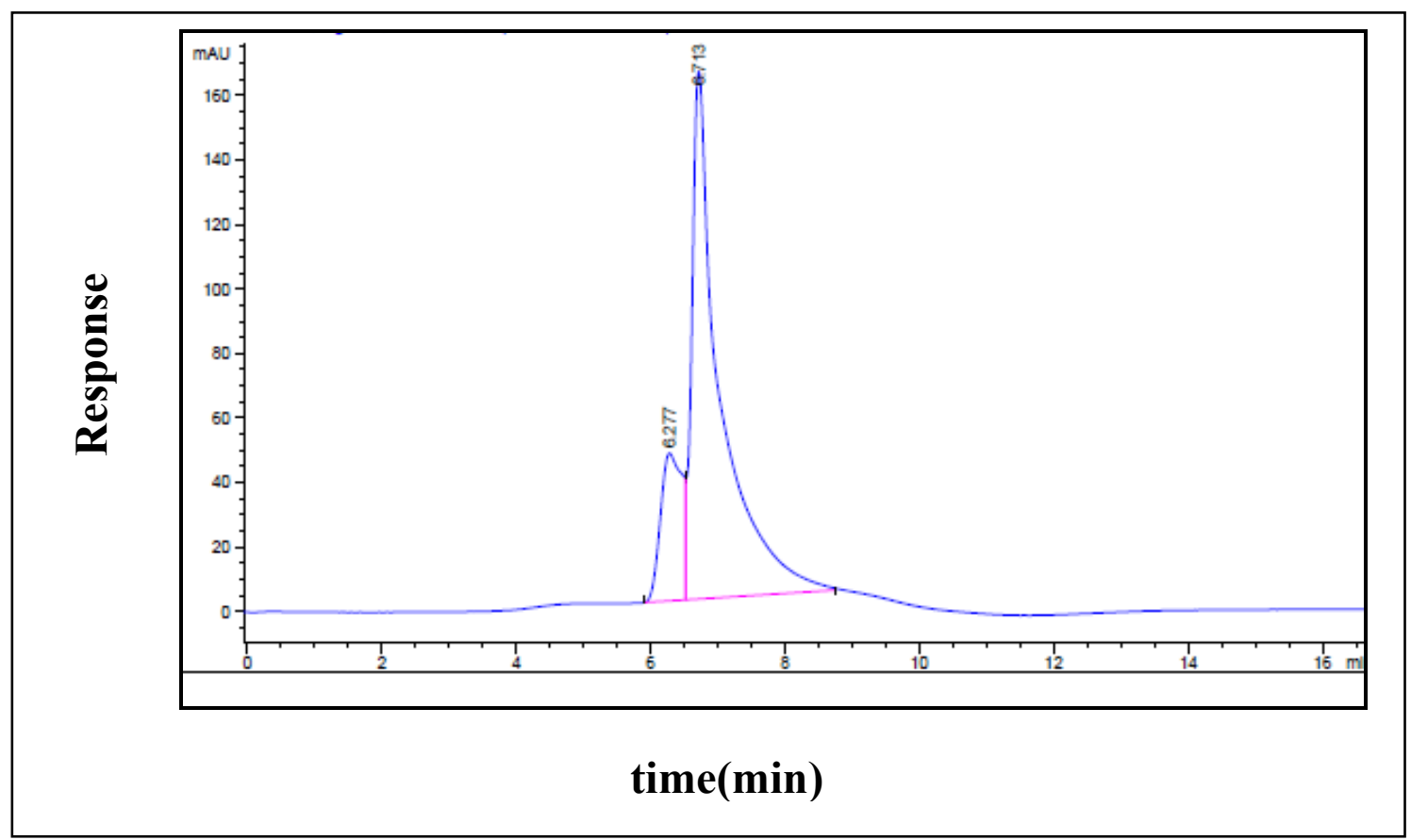

Fig. 4: Chromatogram of obestatin standard solution

Table 2: Obtained data from RP-HPLC of obestatin standard solution and isolated hormone (sample)

\begin{tabular}{|c|c|c|c|c|c|}
\hline $\begin{array}{c}\text { Name of the } \\
\text { solution }\end{array}$ & peak & $\begin{array}{c}\text { Ret. time } \\
\text { (min) }\end{array}$ & width & Area & \%area \\
\hline & 1 & 6.277 & 0.3222 & 1029.688 & 17.6598 \\
Standard & 2 & 6.713 & 0.3944 & 4800.995 & 82.3402 \\
\hline & 1 & 6.448 & 0.1904 & 233.31 & 5.9568 \\
Sample & 2 & 6.776 & 0.4201 & 3472.2 & 88.6521 \\
\hline
\end{tabular}

On the other hand, the results in (Fig. 5) and Table (2) showed that three peaks were appeared after introducing a sample of obestatin (peak D) into RP-HPLC system under the same conditions of standard. The first, second (main peak) and the third peaks were appeared at (6.448), (6.776) and (9.196) min respectively.

After comparing the chromatogram of standard with that of the sample, it was found that there was a good identity between the retention time of standard with sample as shown in (Fig. 4, 5) and Table (2). In order to make sure that the isolated proteinous compound (obestatin) was identical with the standard one, $5,10 \mu 1$ of the standard was added to the sample (peak D) and passed through RP-HPLC under the same conditions as shown 
formerly. The results in (Fig. 6 and 7) and Table (3) demonstrated that the area under the peak of the sample was a gradualy increased with the addition of standard solution to the sample (peak D). Furthermore, the stabilization of retention time after each addition. After comparing the chromatograms in (Figs. 5, 6 and 7), it was found that there was an identity between the obestatin standard and the isolated obestatin hormone (peak D). so this indicated that peak D (obestatin) represent the same properties of standard obestatin.

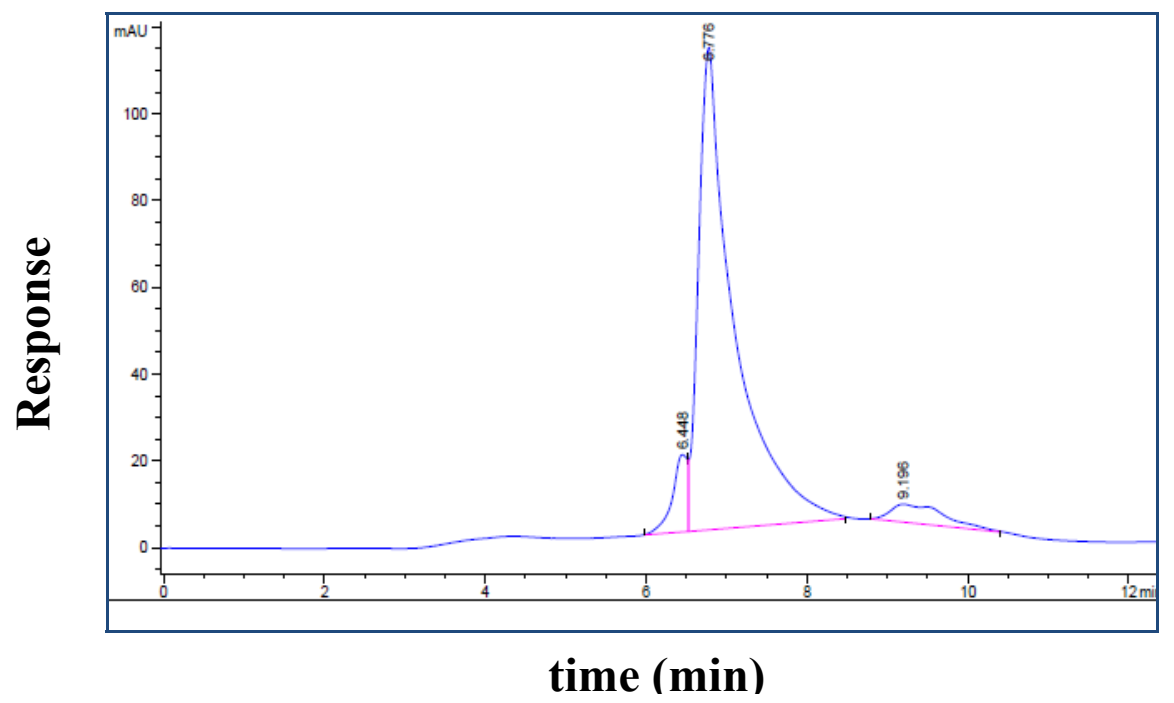

Fig. 5: Chromatogram of sample solution (peak D) from gel filtration (Sephadex G25)

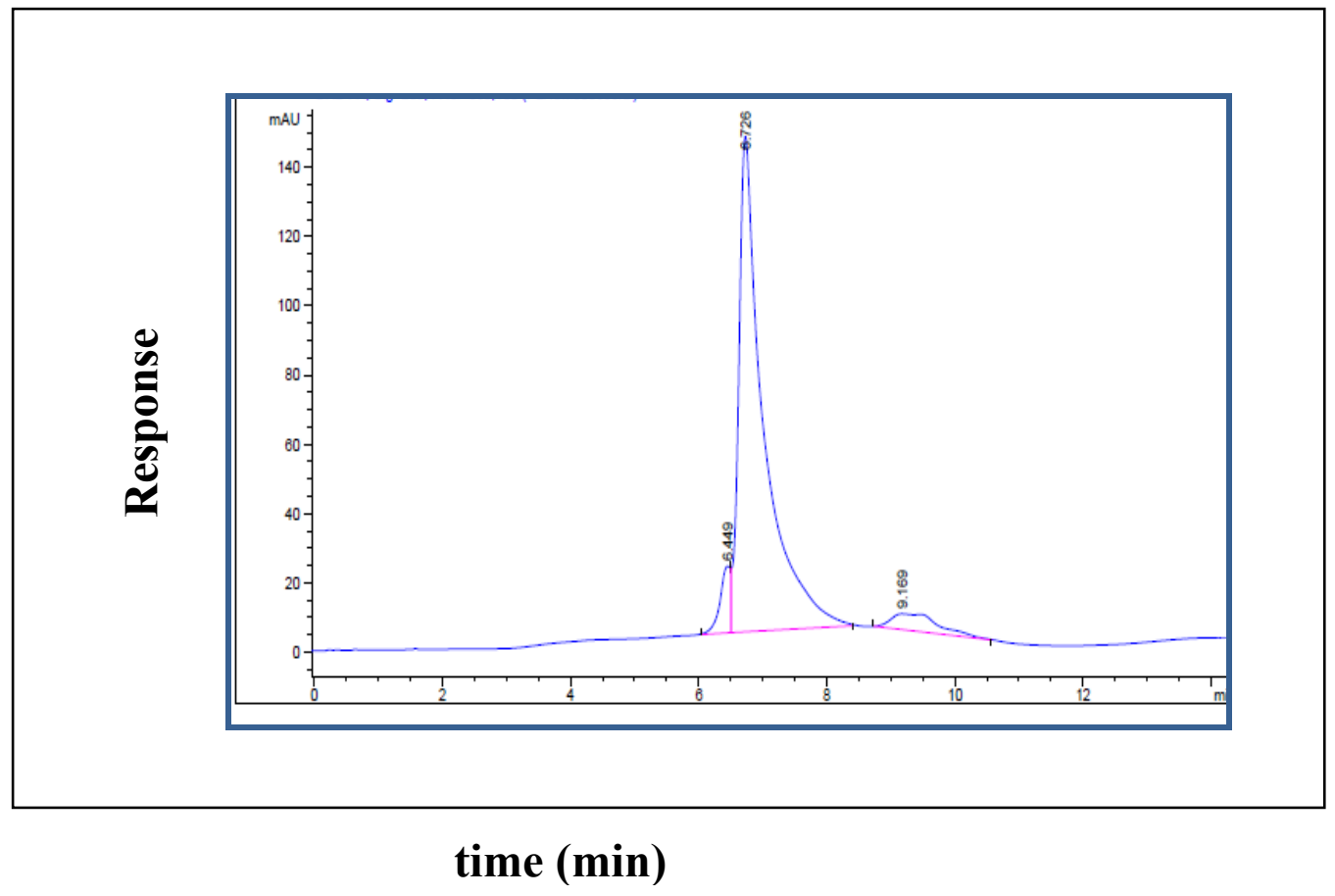

Fig. 6: Chromatogram of sample solution (peak D) from gel filtration (Sephadex G25) after addition of $5 \mu \mathrm{l}$ of obestatin standard solution. 


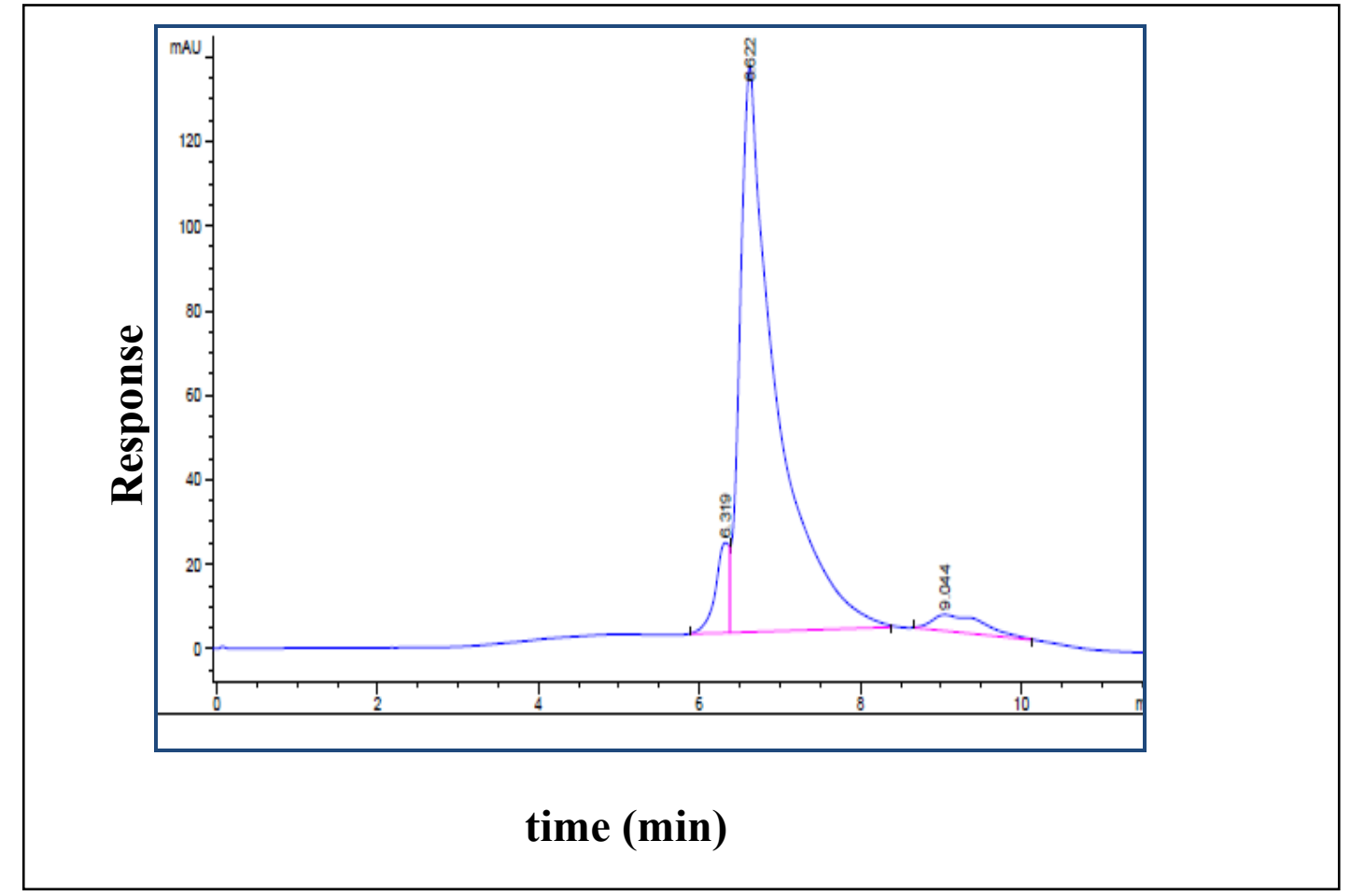

Fig. 7 : Chromatogram of sample solution (peak D) from gel filtration (Sephadex G25) after addition of $10 \mu \mathrm{l}$ of obestatin standard solution.

Table 3: Data from RP-HPLC of sample after addition of 5, 10 $\mu \mathrm{L}$ of obestatin standard solution

\begin{tabular}{|c|c|c|c|c|c|}
\hline Name of the solution & peak & $\begin{array}{c}\text { Ret. time } \\
(\mathbf{m i n})\end{array}$ & width & Area & \%area \\
\hline Sample+5 $\boldsymbol{\mu L}$ standard & 1 & 6.449 & 0.1718 & 221.42609 & 5.0708 \\
obestatin & 2 & 6.726 & 0.3624 & 3882.41406 & 88.91 \\
& 3 & 9.169 & 0.7078 & 262.83627 & 6.0191 \\
\hline Sample+10 $\boldsymbol{\mu L}$ & 1 & 6.319 & 0.1763 & 253.0191 & 5.4658 \\
standard obestatin & 2 & 6.622 & 0.4192 & 4190.5083 & 90.5251 \\
\hline
\end{tabular}

Determination of the molecular weight of obestatin hormone

I- Determination of the molecular weight of obestatin hormone by gel filtration chromatography using sephadex G-25:

The approximate molecular weight of peak (D) as a source of obestatin was determined from the elution volume on a sephadex G-25 column. The calibration curve obtained by using known molecular weight (Table 4) proteins is shown in (Fig. 8). The molecular weight of peak (D) is approximately equal to $(2573 \pm 100)$ Dalton as shown in (Fig. 8). 
Table 4: Elution volumes of known molecular weight materials on sephadex G-25

\begin{tabular}{|c|c|c|}
\hline Materials & $\begin{array}{c}\text { Molecular weight } \\
\text { (Dalton) }\end{array}$ & $\begin{array}{c}\text { Elution volume } \\
\text { (mL) }\end{array}$ \\
\hline Blue dextran & 2000000 & 53 \\
\hline Bovine serum albumin & 67000 & 56 \\
\hline Egg albumin & 45000 & 61 \\
\hline Prolactin hormone & 24000 & 71 \\
\hline Papain & 23000 & 75 \\
\hline Insulin hormone & 5734 & 92 \\
\hline Oxytocin hormone & 1051 & 126.8 \\
\hline Tryptophan & 204 & 186.6 \\
\hline Peak D & 2573 & 112.5 \\
\hline
\end{tabular}

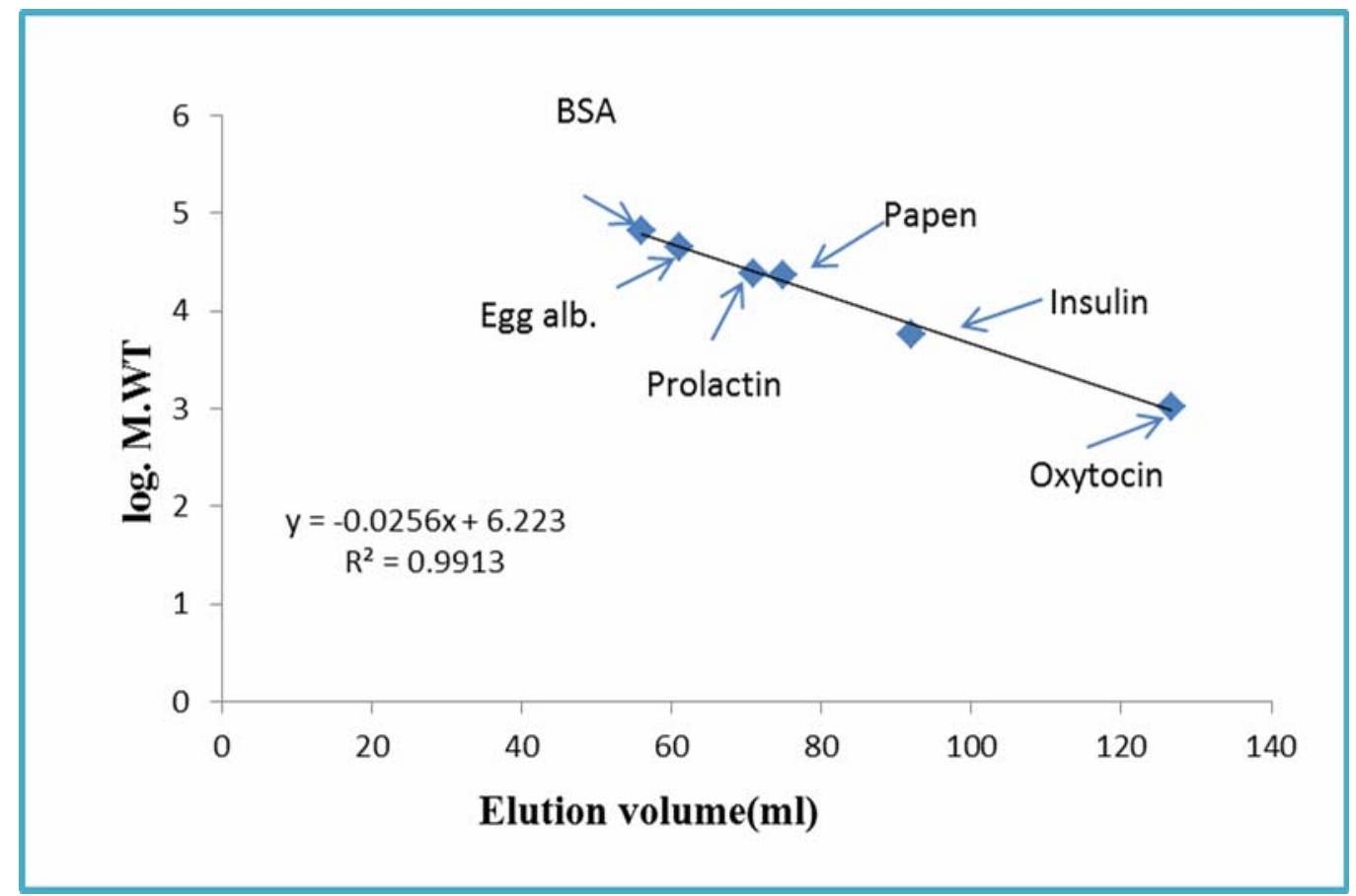

Fig. 8: Relation of molecular weight of known proteins and elution volumes on a Sephadex G-25

\section{II- Determination of molecular weight by SDS-PAGE}

The molecular weight of peak (D) as a source of obestatin was determined, using known molecular weight compounds, and it was found to be in the range of (2660) Dalton as shown in Table (5) and (Fig. 9).

This finding agrees well with the previous results, where it was reported that the molecular weight of obestatin purified from stomach of rats and human plasma was (2500) Dalton (Zhang et al., 2005; Lacquaniti et al., 2011). 
Table 5 :Distance of known molecular weight materials on SDS-PAGE

\begin{tabular}{|c|c|c|}
\hline Materials & $\begin{array}{c}\text { Molecular Weight } \\
\text { (Dalton) }\end{array}$ & $\begin{array}{c}\text { Distant } \\
\text { (cm) }\end{array}$ \\
\hline$\alpha$-amylase & 58000 & 1.1 \\
\hline Egg albumin & 45000 & 1.8 \\
\hline Pepsin & 36000 & 2.2 \\
\hline Papen & 23000 & 3.4 \\
\hline Insulin (without $\beta$-M.E) & 5734 & 5.2 \\
\hline (Insulin + $\beta$-M.E) chain B & 3430 & 6.2 \\
\hline (Insulin + $\beta$-M.E) chain A & 2384 & 6.4 \\
\hline Peak D & 2660 & 6.5 \\
\hline
\end{tabular}

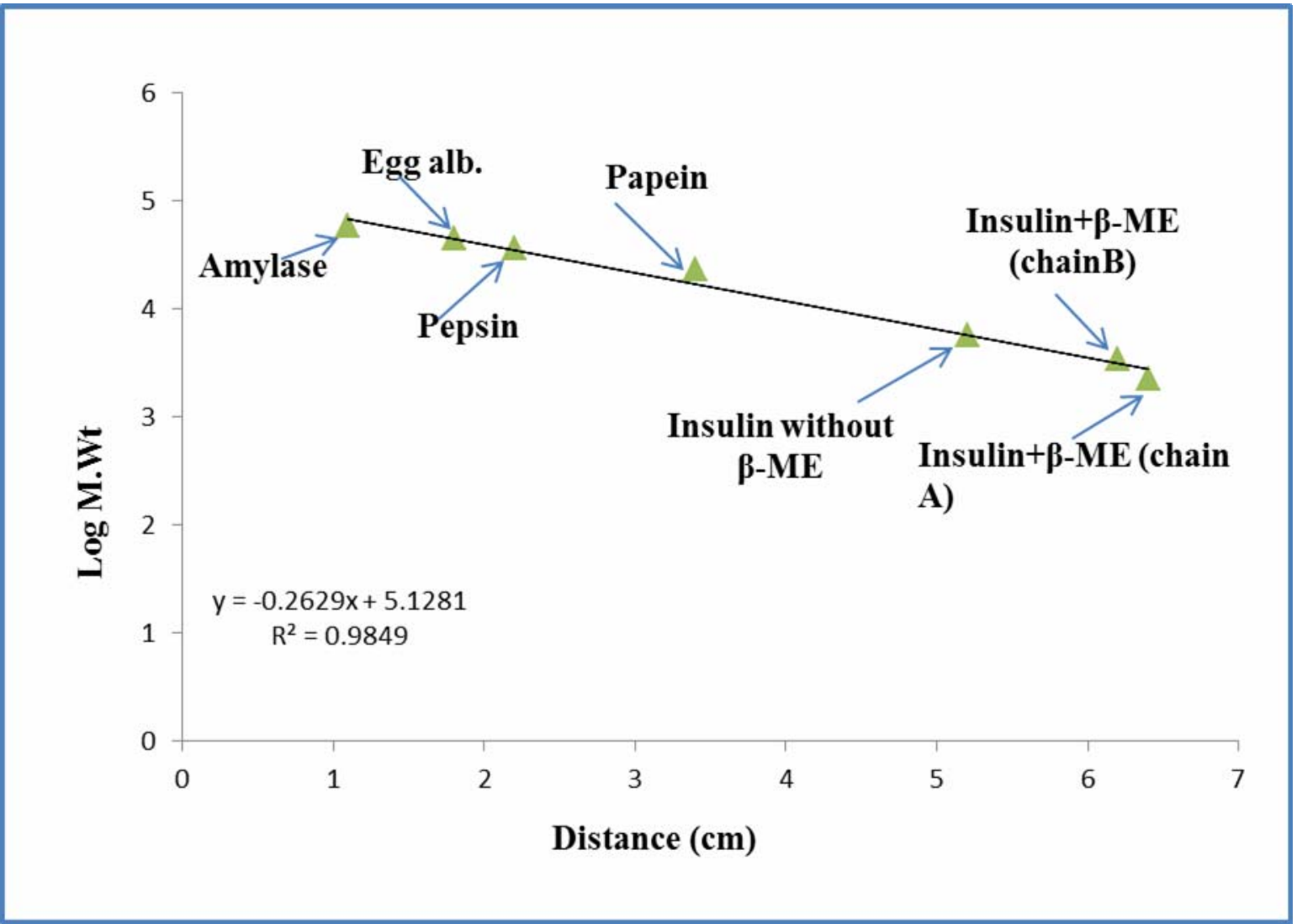

Fig. 9: Calibration curve for molecular weight estimation by SDS-Polyacrylamide gel electrophoresis using known molecular weight proteins

The second part of this research focused on the studding the effect of obestatin (peak D) on normal and diabetic rats.

Effect of isolated obestatin hormone on some biochemical parameters in serum of normal and alloxan-induced diabetic rats.

The results in Table (6) showed that the intraperitoneally injection of $(1 \mu \mathrm{mol} / \mathrm{kg} / \mathrm{day})$ obestatin for a period of one week, the normal and alloxan induced diabetes rats caused a 
significant decrease in serum glucose level compared to the control groups which are related to these groups (group 1 and 2). These results were in agreement with those obtained by other investigators (Granata et al., 2012). These reductions could be attributed to the important role of obestatin in stimulation the insulin biosynthesis, glucose uptake in either absence or presence of insulin, promoting glucose transporter type 4(GLUT4) translocation, whereas GLUT4 plays the role of tissue glucose uptake and regulates the body glucose homeostasis (Garanta et al., 2012; Gandhi et al., 2013). Further more, obestatin promoting survival and preventing apoptosis in $\beta$-cells of pancreas and up regulating of glucokinase expression (Granata et al., 2008). Furthermore, the treatment with obestatin might cause an increase of $\beta$-cells mass like ghrelin (Granata et al., 2012). Also the reduction of glucose level might cause the induction of adiponectin, whereas adiponectin decreases gluconeogensis, while the increase in glucose uptake and level lead to increase insulin sensitivity (Huerta, 2006).

Moreover, the results also showed that there was a significant decrease of serum total lipids compared to the control group which is related to these groups. This might be due to the role of obestatin in inhibiting food intake (Nagaraj et al., 2009; Brunelti et al., 2010), and the role of obestatin in inhibiting gastric emptying and gastrointestinal motility (Zhang et al., 2005; Fujimiya et al., 2011).

The results in Table (6) revealed that there were a significant decrease in total serum cholesterol, triglycerides, LDL-C and VLDL-C levels compared to control groups which were related to those groups. These results were in agreement with those obtained by other investigators (Nagaraj et al., 2009; Aragno et al., 2012). The reduction might be due to that obestatin increase the phosphorylation of AMP-activated protein kinase (AMPK) (Bourron et al., 2010) and then inhibit HMG-CoA reductase which contributes in biosynthesis of cholesterol (Agnew et al., 2011). Also, the phosphorylation of AMPK will inhibit acetyl CoA carboxylase which contributes in biosynthesis of fatty acid and triglycerides (Fogarty et al., 2010).

On the other hand, the results also showed that there was a significant increase inserum HDL-C levels compared to control groups which were related to these groups. The cause might due to that obestatin stimulates insulin secretion, so the activity of lipoprotein lipase will be increased and leads to increase HDL-C (Granata et al., 2008), or the cause might be due to that obestatin induced phosphorylation of AMPK and this will reduce inflammatory markers such as TNF- $\alpha$ and IL-6 (Arango et al., 2012) and lead to induce adiponectin which correlates positively with HDL-C (Hsu et al., 2012; Allwsh and Mohammad, 2013).

Furthermore, the results in Table (6) show that there was a significant decrease in serum MDA level compared to control groups which were related to these groups. The reason might be due to the ability of obestatin to restore oxidative balance and leads to decrease oxidative stress and ROS. So, obestatin exerts protective effect against oxidative stress (Arango et al., 2012), or the cause might be attributed to the antioxidant properties of adiponectin (Raucci et al., 2013), which correlated positively with obestatin (Allwsh and Mohammad, 2013). 
Table 6: Effect of intraperitoneally injection of isolated obestatin hormone for a period of one week on some biochemical parameters on normal and alloxan-induced diabetic males rats

\begin{tabular}{|c|c|c|c|c|c|c|c|c|c|c|}
\hline $\begin{array}{l}\text { Group } \\
\text { No. }\end{array}$ & $\begin{array}{r}\text { biochemical } \\
\text { parameters }\end{array}$ & $\begin{array}{c}\text { Glu } \\
\text { mmol/L }\end{array}$ & $\begin{array}{c}\text { T.L } \\
\text { mg/dL }\end{array}$ & $\begin{array}{c}\text { T.C } \\
\text { mmol/ L }\end{array}$ & $\begin{array}{c}\text { T.G } \\
\text { mmol/ L }\end{array}$ & $\begin{array}{l}\text { LDL-C } \\
\mathrm{mmol} / \mathrm{L}\end{array}$ & $\begin{array}{l}\text { VLDL-C } \\
\mathrm{mmol} / \mathrm{L}\end{array}$ & $\begin{array}{c}\text { HDL } \\
\mathrm{mmol} / \mathrm{L}\end{array}$ & $\begin{array}{c}\text { MDA } \\
\mu \mathrm{mol} / \mathrm{L}\end{array}$ & GSH \\
\hline 1 & Control + N.S & $\begin{array}{c}\text { (b) } \\
4.86 \pm 0.1\end{array}$ & $\begin{array}{c}\text { (b) } \\
767.02 \\
\pm 3.61\end{array}$ & $\begin{array}{c}\text { (b) } \\
3.46 \pm \\
0.22\end{array}$ & $\begin{array}{c}\text { (b) } \\
1.29 \pm \\
0.06\end{array}$ & $\begin{array}{c}\text { (b) } \\
2.01 \pm \\
0.32\end{array}$ & $\begin{array}{c}\text { (b) } \\
0.56 \pm 0.02\end{array}$ & $\begin{array}{c}\text { (b) } \\
1.22 \pm \\
0.07\end{array}$ & $\begin{array}{l}\text { (b) } \\
1.4 \pm \\
0.14\end{array}$ & $8.16^{(1}$ \\
\hline 2 & $\begin{array}{c}\text { Diabetic rats (untreated } \\
\text { with obestatin)+N.S }\end{array}$ & $\begin{array}{c}(d) \\
22.24 \pm 0.22\end{array}$ & $\begin{array}{c}(\mathrm{c}) \\
880.16 \\
\pm 4.48\end{array}$ & $\begin{array}{c}(\mathrm{c}) \\
4.92 \pm \\
0.23\end{array}$ & $\begin{array}{c}(\mathrm{c}) \\
2.35 \pm \\
0.29\end{array}$ & $\begin{array}{c}(\mathrm{c}) \\
3.07 \pm \\
0.29\end{array}$ & $\begin{array}{c}(\mathrm{c}) \\
1.06 \pm 0.09\end{array}$ & $\begin{array}{c}\text { (a) } \\
0.78 \pm \\
0.06\end{array}$ & $\begin{array}{c}(\mathrm{c}) \\
3.9 \pm \\
0.25\end{array}$ & $4.32=$ \\
\hline 3 & $\begin{array}{c}\text { Normal rats }+(1 \mu \mathrm{mol} / \\
\mathrm{kg} / \mathrm{d}) \text { of isolated } \\
\text { obestatin hormone }\end{array}$ & $\begin{array}{c}\text { (a) } \\
3.24 \pm 0.41\end{array}$ & $\begin{array}{l}\text { (a) } \\
611.46 \\
\pm 2.4\end{array}$ & $\begin{array}{c}\text { (a) } \\
2.51 \pm \\
0.06\end{array}$ & $\begin{array}{c}\text { (a) } \\
0.89 \pm \\
0.07\end{array}$ & $\begin{array}{c}\text { (a) } \\
0.65 \pm \\
0.09\end{array}$ & $\begin{array}{c}\text { (a) } \\
0.40 \pm 0.01\end{array}$ & $\begin{array}{l}(\mathrm{c}) \\
1.55 \pm \\
0.05\end{array}$ & $\begin{array}{c}\text { (a) } \\
0.82 \pm \\
0.06\end{array}$ & $9.10=$ \\
\hline 4 & $\begin{array}{c}\text { Diabetic rats }+(1 \mu \mathrm{mol} / \\
\mathrm{kg} / \mathrm{d}) \text { of isolated } \\
\text { obestatin }\end{array}$ & $\begin{array}{c}(\mathrm{c}) \\
7.29 \pm 0.26\end{array}$ & $\begin{array}{c}\text { (b) } \\
743.42 \\
\pm 8.28\end{array}$ & $\begin{array}{c}\text { (b) } \\
3.56 \pm \\
0.07\end{array}$ & $\begin{array}{c}(\mathrm{ab}) \\
1.01 \pm \\
0.11\end{array}$ & $\begin{array}{c}\text { (b) } \\
1.48 \pm \\
0.12\end{array}$ & $\begin{array}{c}(\mathrm{ab}) \\
0.45 \pm 0.02\end{array}$ & $\begin{array}{c}(\mathrm{c}) \\
1.61 \pm \\
0.12\end{array}$ & $\begin{array}{c}\text { (b) } \\
1.74 \pm \\
0.13\end{array}$ & 8 \\
\hline
\end{tabular}

Different letters vertically (a),(b),(c),(d), indicate that the mean are different significantly at $\mathrm{P} \leq 0.05$ between each group after one week of treatment, the values are mean \pm S.E of six rats each group, N.S, normal saline. 
The results ( Table 6) also showed that there were a non significant increase inserum GSH level compared to control group which related to this group, while caused a significant increase of GSH level in alloxan induced diabetic mals rats. The results were in agreement with those obtained by other investigators (Arango et al., 2012), who found the ratio of GSSG/GSH was partially decreased when the diabetic rats treated with obestatin and showed that obestatin exerted protective effects against oxidative stress.

Furthermore, the results in Table (6) showed that there were no significant differences in GPT, GOT, ALP and ACP levels after intraperitoneally injection of $(1 \mu \mathrm{mol} / \mathrm{kg} / \mathrm{d})$ for one week in normal and alloxan induced diabetic males rats.

\section{REFERENCES}

Agnew, A.; Calderwood, D.; Chevallier, O.P.; Green, B.; Grieve, D.J.; Green, B.D. (2011). Chronic treatment with a stable obestatin analog Significantly alters plasma triglyceride levels but fails to influence food intake; fluid intake; body weight; or body composition in rats. Peptides, 32(4), 755-762.

Alen, B.O.; Nieto, L.; Gurriaran-Rodriguez, U.; Mosteiro, C. S.; Alvarez-perez, J.C.; Alen, M.O.; Camina, J.P.; Galleg, O.M.R.; Garcia-Caballero, T.; Martin-Pastor, M.; Casanueva, F.F.; Jimenez-Baebero, J.; Pazos, Y. (2012). The NMR structure of human obestatin in membrane-like environments: insights into the structure bioactivity relationship of obestatin. Plos One, 7(10),1-16.

Allain, C.C.; Poon, L.S.; Chan, C.S.; Richmond, W.; Fu, P.C. (1974). Determination of serum total cholesterol by enzymatic colorimetric method. Clin. Chem., 20 (4), $470-475$.

Allwsh, T.A.; Mohammad, J.A. (2013). Clinical Study of Obestatin Hormone and Its Relation to Diabetes Mellitus. Raf. J. Sci.24(4),74-87.

Aragno, M.; Mastrocola, R.; Ghe, C.; Arnoletti, E.; Bassino, E.; Alloatti, G.; Muccioli, M. (2012). Obestatin induced recovery of Myocardial dysfunction in type 1 diabetic rats: underlying Mechanisms. Cardiovascular Diabetology, 11,129-139.

Bourron, O.; Daval, M.; Hainault, I.; Hajduch, E.; Servant, J.M.; Gautier, J.F.; Ferre, P.; Foufelle, F. (2010). Biguanides and thiazolidinediones Inhibit stimulated lipolysis in human adipocytes through activation of AMP-activated protein kinase. Diabetologia, 53, 768-778.

Brunelti, L.; Di Nisio, C.; Recinella, L.; Orlando, G.; Ferrante, C.; Chiavaroli, A.; Leone, S.; Di Michele, P.; Shohreh, R.; Vacca, M. (2010). Obestatin inhibits dopamine release in rat hypothalamus. Eur. J. Pharmacol., 641,142-147.

Burtis, C.A.; Ashwood, E.R. (1982). "Tietz Fundamental of Clinical Chemistry". 2nd ed. W. B. Saunders company, U. S. A., pp. 302, 337, 539, 901.

Chabrol; Chardonnet (1937). Cited by Al-Mollah L.A.M. (1990). Studies of some metabolic effects of Noradrendine insulin inpresence of $\mathrm{Ca}^{++}$. M. Sc. Thesis, Department of Chemistry, University of Mosul, Iraq.

Cuping, Z.; Dongmei, K. (2009). Changes of plasma obestatin and ghrelin in diabetes mellitus. Chinese J. Clinical Health Care, 22(6), 589-591

Dong, X.Y.; He, J.M.; Tang, S.Q.; Li, H.Y; Jiang, Q.Y ; Zou, X.T. (2009). Is GPR39 the natural receptor of obestatin? Peptides, 30, 431-438. 
Fischbach, F. (2000). "A Manual of Laboratory and Diagnostic Tests". 6th ed. Lippincott Williams and wikins, U. S. A., 472 p.

Fogarty, S.; Hardie D.G. (2010). Development of protein kinase activators: AMPK as a target in metabolic disorders and cancer. Biochem. Biophys. Acta., 1804, 581591.

Fossati, P.; Prencipe, L. (1982). Serum triglycerides determined colorimetrically with an enzyme that produces hydrogen peroxide. Clin. Chem., 28(10), 2077-2080.

Fujimiya, M.; Ataka, K.; Asakawa, A.; Chen, C.Y.; Kato, I.; Inui, A. (2011). Ghrelin, des-acyl ghrelin and obestatin on the gastrointestinal Motility. Peptides, 32(11), 2348-2351.

Gandhi, G.R.; Stalin, A.; Balakrishna, K.; Ignacimuthu, S.; Paulraj, M.G.; Vishal, R. (2013). Insulin sensitization via agonism of PPAR $\gamma$ and glucose uptake through translocation and activation of $\mathrm{GLUT}_{4}$ in $\mathrm{PI}_{3} \mathrm{~K} / \mathrm{P}$-Akt signaling pathway by embelin in type 2 Diabetic rats. Biochimica et Biophysica Acta., 1830, 2243-2255.

Granata, R.; Baragli, A.; Settanni, F.; Scarlatti, F.; Ghigo, E. (2010b) Unraveling the role of the ghrelin gene peptides in the endocrine pancreas. J. Molecular Endocrinology, 45, 107-118.

Granata, R.; Gallo, D.; Luque, R.M.; Baragli, A.; Scarlatti, F.; Grande, C.; Gesmundo, I.; Cordoba-Chacon, J.; Bergandi, L.; Settanni, F.; Togliatto, Rocchietto, S.; Matera, L.; Datta, G.; Morino, M.; Brizzi, M.F.; Ong, H.; Camussi, G.; Castano, J.P.; Papotti, M.; Ghigo, E. (2012). Obestatin Regulates adipocyte function and protects against diet - induced insulin Resistance and inflammation. The Faseb J., 26, 3393-3411.

Granata, R.; Settanni, F.; Gallo, D.; Trovato, L.; Biancone, L.; Cantaluppi V.; Nano, R.; Annunziata, M.; Campiglia, P.; Arnoletti, E.; Ghe, C.; Volante, M.; Papotti, M.; Muccioli; G.; Ghigo, E. (2008). Obestatin promotes Survival of pancreatic beta-cells and Human islets and induces expression of genes involved in the regulation of beta-cell mass and function. Diabetes, 57, 967979.

Green, B.D.; Irwin, N.; Flatt, P.R. (2007). Direct and indirecteffects of Obestatin peptides on food intake and the regulation of glucose homeostasis and insulin secretion in mice. Peptides, 28, 981-987.

Guidet, B.; Shah, S.V. (1989). Am. J. Physiol. 257(26): f440. Cited by Muslih, R.K.; AlNimer, M.S.; Al-Zamely, O.M. (2002). The level of malondialdehyde after activation with $\left(\mathrm{H}_{2} \mathrm{O}_{2}\right.$ And $\left.\mathrm{CuSO}_{4}\right)$ and inhibition by desferoxamine and molsidomine in the serum of patients with acute myocardial infraction. Nation. J. Chem. 5,139-148.

Hsu, C.H.; Liao, Y.L.; Lin, S.C.; Chou, P. (2012). Adiponectinlevel Predicts HDL Cholesterol level in type 2 diabetes. The Open Atherosclerosis and Thrombosis J., 5, 1-5.

Huerta, M.G. (2006). Adiponectin and leptin: Potential tools in the differential diagnosis of pediatric diabetes. Rev. Endocr. Metab. Disord., 7, 187-196.

Ishitobi, Y.; Akiyoshi, J.; Honda, S.; Ninomiya, T.; Kanehisa, M.; Tanaka, Y.; Tsuru, J.; Isogawa, K.; Kitamura, H.; Fujikura, Y. (2012). GPR39-1b causes anxilytic-like Responses and appetite loss in rats. Neuroscience Research, 72(3), 257-262. 
Jahan, S.; Sidrat, T.; Ahmed, S.; Wazir, H. and Ullah, K. (2011). Effect of Obestatin on morphometry of testes and testosterone secretion in male Rats. African J. Biotechnology. 10(39), 7717-7722.

Kind, P.R.; King, E.G. (1954). Estimation of plasma phosphade by determination of hydrolysed phenol with amino antipyrine. J. Clim. Pathnol., 7, 322-326.

Kirkwood, B.R. (1988). "Essentials of Medical Statistics". 1st ed., Black well Scientific Publication, Oxford; pp. 43-56.

Lacquaniti, A.; Donato, V.; Chirico, V.; Pettinato, G.; Buemi, M. (2011). From chronic kidney disease to transplantation: The roles of obestatin. Regulatory Peptides, 171(1-3), 48-52.

Laemmli, U.K. (1970). Cleavage of structural proteins during the assembly of the head of bacteriophage T4. Nature, 227, 680-685.

Lopez-Verella, M.F.; Stone, P.; Ellis, S.; Glwell, J.A. (1977). Cholesterol determination in high density lipoprotein separated by three different methods. Clin. Chem., 23, 882884.

Miura, T.; Usami, M.; Tsuura, Y.; Ishida, H.; Seino, Y. (1995). Hypoglycemic and hyolipidemic effect of chitosan in normal and neonatal streptozotocin induced diabetes mice. Biol. Pharm. Bull., 18(1),1623-1625.

Mondal, M.S.; Toshinai, K.; Ueno, H.; Koshinaka, K.; Nakazato, M. (2008). Characterization of obestatin in rat and Human stomach and Plasma, and its lack of acute effect on feeding behavior in rodents. J. Endocrinology, 198, 339346.

Nagaraj, S.; Peddha, M.S.; Manjappara, U.V. (2009). Fragmentsanalogs as better mimics of obestatin. Regul. Pept., 158, 143-148.

Raucci, R.; Rusolo, F.; Sharma, A.; Colonna, G.; Castello, G.; Costantini, S. (2013). Functional and structural features of adipokine family. Cytokine, 61, 1-14.

Reitman, S.; Frankel, S. (1957) . A colorimetric method for the determination of serum glutamic oxaloacetic and glutamic pyruvic transaminases. Am. J. Clin. Pathol. 28, $56-63$.

Ren, A.J.; Guo, Z.F.; Wang, Y.K.; Wang, L.G.; Wang, W.Z.; Lin, L.; Zheng, X.; Yuan, W.J. (2009). Inhibitory effect of obestatin on glucose-induced Insulin secretion in rats. Biochem. Biophys. Res. Commun, 369, 969-972.

Schacterle, G.R.; Pollack, R. L. (1973). A simplified method for the quantitatiue assay of small amounts of protein biological material. Anal. Biochem. 51, 654-655.

Seadlak, J.; Lindsay, R.H. (1968). Analytical Biochemistry.192, Cited by Al-Zamyle, O.M, Al-Nimer M.S, Al-Muslih R.K. (2001). Detection the levelof peroxynitrite and related with antioxidant satus in the serum of patients with acute myocardial ifraction. Nation. J. Chem, 4, 625-637.

Semi, I.; Walpole, C.; Amorim, L.; Josh, P.; Herington, A.; Chopin, L. (2011). The expanding roles of the ghrelin-gene derived peptide Obestatin in health and disease. Molecular and Cellular Endocrinology. 340, 111-117.

Subasinghage, A.P.; Green, B.D.; Flatt, P.R.; Irwin, N.; Hewage, C.M. (2010). Metabolic and structural properties of human obestatin (1-23) and two fragment peptides. Peptides, 31, 1697- 1705. 
Tomoda, M.; Shimizu, N.; Gonda R.; Kanari, M.; Yamada, H.; Hikino, H. (1990). AntiComplementary and hypoglycemic activities of the glycans from the seeds of malva verticillata. Planta Med., 56, 168-170.

Trinder, P. (1969). Determination of glucose in blood using glucose oxidease with an all ernative oxygen occeptor. Ann. Clin. Biochem., 6, 24-33.

Volante, M.; Rosas, R.; Ceppi, P.; Rapa, I.; Cassoni, P.; Wiedenmann, B.; Settanni, F.; Granata, R.; Papotti, M. (2009). Obestatin in human Neuroendocrine tissues and tumours: expression and effect on tumour Growth. J. Pathology, 218, 458466.

Zhang, J.V.; Ren, P.G.; Avsian - Kretchmer, O.; Luo, C.W.; Rauch, R.; Klein, C.; Hsueh, A.J. (2005). Obestatin, apeptide encoded by the Ghrelin gene, opposes ghrelin's effects on food intake. Science, 310, 996-999.

Zhang, J.V.; Jahr, H.; Luo, C.V.; Klein, C.; Van Kolen, K.; Ver Donck, L.; De, A.; Beart, E.; Li, J.; Moechars, D.; Hsueh, A.J. (2008). Obestatin Induction of early-response gene expression in gastrointestinal and Adipose tissues and the mediatory role of G protein-coupled receptor, GPR39. Mol Endocrinol., 22, 1464-1475. 